\title{
Política criminal e retórica: contribui- ções para o desenvolvimento de uma nova abordagem para a análise da discursividade parlamentar brasileira ${ }^{1}$
}

Criminal policy and rhetoric: contributions for the development of a new approach to the analysis of Brazilian parliamentary discursiveness

\section{Ricardo Jacobsen Gloeckner ${ }^{2}$ \\ Marcelo Buttelli Ramos ${ }^{3}$}

Resumo: O artigo propõe-se verificar o potencial heurístico da Retórica e das suas figuras de linguagem vis-a-vis uma análise discursiva qualitativa da discursividade parlamentar brasileira. Para este objetivo,

1 O presente trabalho foi realizado com apoio da Coordenação de Aperfeiçoamento de Pessoal Nivel Superior - Brasil (CAPES)

2 Pós-Doutor em Direito pela Università Frederico II (2016). Doutor em Direito pela Universidade Federal do Paraná (2010). Coordenador da Especialização em Ciências Penais da Pontifícia Universidade Católica do Rio Grande do Sul. Professor do Programa de Pós-Graduação em Ciências Criminais da Pontifícia Universidade Católica do Rio Grande do Sul. E-mail: ricardogloeckner@hotmail.com

3 Mestre e Doutorando em Ciências Criminais pela Pontifícia Universidade Católica do Rio Grande do Sul (2016). Pesquisador vinculado ao grupo de pesquisa "Pensamento Político e Criminológico" do Programa de Pós-graduação em Ciências Criminais da Pontifícia Universidade Católica do Rio Grande do Sul. Bolsista pela Coordenação de Aperfeiçoamento de Pessoal de Nível Superior (PROSUC/CAPES). E-mail: buttelliadv@gmail.com 
foram delineadas três linhas argumentativas a partir da análise de um conjunto de discursos relacionados à Lei dos Crimes Hediondos. Na primeira linha argumentativa, foi debatida a centralidade da metáfora para a compreensão do processo de significação da realidade que serve de fundamento para a afirmação do caráter hegemônico da intervenção jurídico-penal; na segunda, foi elucidada a importância da sinédoque para a compreensão da dinâmica implicada no processo (discursivo) de construção das identidades políticas coletivas comumente invocadas pelos legisladores; na terceira, foi analisada a vocação catacrética do significante "hediondo". Finalmente, foram apresentadas as razões pelas quais as figuras retóricas analisadas neste trabalho podem ser consideradas úteis para a análise da discursividade constituída, no parlamento brasileiro, em torno de temas associados à questão criminal.

Palavras-chave: Política Criminal; Retórica; Análise de Discurso; Lei dos Crimes Hediondos; Pós-estruturalismo.

Abstract: The article proposes to verify the heuristic potential of Rhetoric and its figures of speech vis-a-vis a qualitative discursive analysis about the Brazilian parliamentary discursiveness. To achieve this objective, three argumentative lines were drawn from the analysis of a set of discourses related to the Law of the Hideous Crimes. In the first one, the metaphor's centrality for understanding the reality signification process that supports the affirmation of the hegemonic character of criminal legal intervention were debated; in the second, the importance of synecdoche for understanding the dynamics implied in the construction of collective political identities that are commonly invoked by the legislators were elucidated; in the third, the catacress vocation of the "hideous" signifier 
were addressed. Finally, were presented the reasons why the rhetorical figures analyzed in this paper can be considered useful for an analysis of the discursiveness that are constituted, in the Brazilian parliament, towards issues associated with the criminal question.

Key-words: Criminal Policy; Rhetoric; Discourse Analysis; Hideous Crimes Law; Post-structuralism.

Sumário: 1. Introdução: assentando os pressupostos teóricos do debate - 2. A plenitude presentificada no vazio semântico do significante "hediondo" - 3 . Sinédoque e catacrese: construindo o "povo", significando o "hediondo". Considerações finais. Referências bibliográficas.

Summary: 1. Introduction: presenting the theoretical presuppositions of the debate -2 . The fullness presentified in the semantic void of the "hideous" signifier - 3. Synecdoche and catacress: constructing the "people", signifying the "hideous". Final considerations. Bibliographical references.

\section{Introdução: assentando os pressupostos teó- ricos do debate}

Para que se possa compreender com clareza o propósito e o alcance deste empreendimento teórico capitaneado por Ernesto Laclau, relativamente à utilização das figuras da retórica como instrumentos ancilares para o estudo dos discursos políticos, em primeiro lugar importa esclarecer o tipo de pressuposições teóricas e ontológicas assumidas autor e, consequentemente, o sentido por ele atribuído à noção de discurso.

A teoria política de Ernesto Laclau encontra seu fundamento na chamada ontologia pós-estruturalista. Não é nosso 
intento neste escrito detalhar os inúmeros aspectos constitutivos dessa particular instância de reflexões sobre o ser, pois existem inúmeros trabalhos dedicados ao enfrentamento dessa questão ${ }^{4}$. Quando afirmamos que a teoria política engendrada pelo autor se alinha à tradição pós-estruturalista, queremos dizer que as suas categorias teóricas partem da pressuposição de que não existem leis causais universais, nem necessidades lógicas estritamente formais e, portanto, transcendentais, capazes de determinar a priori a essência do ente. De acordo com tal pressuposição, o ser do ente se revela nas injunções (discursivas) contextuais a partir das quais ele é invocado e, portanto, significado.

Deve-se notar que as pressuposições ontológicas estampadas na teoria política laclauniana fincam raízes na ideia da “diferença ontológica" e no esforço empreendido por Martin Heidegger em relação à superação do pensamento metafísico. Nesse sentido, ganha destaque a categoria heideggeriana do Abgrund, que separa a dimensão ôntica da ontológica.

A representação do plano ontológico através da metáfora do "abismo" indica, na esteira do entendimento preconizado por Laclau, não a ausência de um plano ontológico, mas a marca de uma falta que, nos termos utilizados por Jacques Derrida, se inscreveria na própria estrutura, impedindo-lhe de reclamar o status de totalidade. Assim, se a dimensão ontológica da realidade representa per se uma ausência incomensurável, as tentativas de acesso à sua essência invariavelmente dar-se-ão por intermédio de representações distintas e concorrentes entre si e, portanto, necessariamente parciais. Em síntese, parte-se do pressuposto de que o ente só pode ser pensado a partir do ser. Em termos sociológicos, a referida assertiva poderia ser reconfigurada da seguinte

4 LACLAU; MOUFFE, 2015; GLYNOS; HOWART, 2007; MENDONÇA, 2014; MARCHART, 2007. 
maneira: a "realidade" social não constitui uma objetividade, uma positividade; pelo contrário, o próprio caráter "real" do social é determinado a partir - nunca antes - de um processo significativo, hermenêutico. A assunção dessa proposição implicará, para Laclau, na seguinte conclusão: “dado que não há um fundamento último, também não pode haver uma fixação última do significado." 5 .

Importante referir, contudo, acerca deste último argumento, que a ontologia pós-estruturalista não se confunde em absoluto com a perspectiva anti-estruturalista (tome-se, por exemplo, as propostas de um anarquismo epistemológico defendidas por Paul Feyerabend), tampouco com "certo tipo de pós-modernismo apocalíptico que gostaria que acreditássemos que nos encontramos no limiar de uma época caracterizada [...] pelo incontrolável jogo das significações." ${ }^{\text {. }}$ Com efeito, ao preconizar a inexistência de fundamentos últimos, transcendentais ou absolutos, Laclau não está a sugerir a inexistência de fundamentos, antes pelo contrário, o autor os reconhece, mas apenas sob a condição de serem considerados, na esteira do conceito idealizado por Judith Butler ${ }^{7}$, fundamentos contingentes. ${ }^{8} \mathrm{O}$ que se pretende, portanto, na tradição teórica pós-estruturalista, da qual Laclau é, certamente, um dos seus maiores expoentes, é demonstrar o enfraquecimento do status ontológico da ideia de fundamento e não sua inexistência.

5 LACLAU, 2014, p. 118.

6 MOUFFE, 1996, p. 29.

7 BUTLER, 1998.

8 A noção de contingência, um dos mais destacados axiomas da teoria pós-estruturalista, foi muito claramente definida por Mendonça e Rodrigues: "A de contingência é inimiga da concepção teleológica de histórica, representada em metarrelatos e/ou narrativas universalizantes de predição social. Pensar a partir da continência impede-nos de tomarmos as relações sociais para além de injunções contextualizadas". (MENDONÇA; RODRIGUES, 2014, p. 50). 
Neste sentido, embora a tradição teórica pós-estruturalista tenha se consolidado em razão das agudas críticas formuladas às pretensões (metafísicas) propugnadas pela matriz estruturalista ${ }^{9}$, torna-se necessário enfatizar que a teoria pós-estruturalista ainda se encontra às voltas com a noção de um elemento central que articula e ordena o processo de significação da realidade. ${ }^{10} \mathrm{O}$ que determinada o caráter central deste elemento, contudo, já não é mais uma lei imanente, logicamente determinável e alheia a toda e qualquer injunção contextual, mas sim relações de poder que operam e se desenvolvem no plano dos discursos.

A partir do desenvolvimento das hipóteses derridianas clássica e pós-clássica"1 , a noção de "centro" deixa de ser

9 Hoje é reconhecimento que um dos mais destacados propósitos das teorias pós-estruturalistas consiste no cancelamento dos traços daquilo que Derrida chamou de metafísica da presença. (DERRIDA, 2014, p. 410). A noção caracteriza-se, em suma, pela crença - assentada, inicialmente, pela linguística de Ferdinand de Saussure (2014), e, posteriormente, desenvolvida nos escritos antropológicos de Lévi-Strauss - na existência de estruturas fundamentais que, fundadas em postulados invariantes mínimos, determinariam, a despeito de qualquer injunção ou particularidade contextual/ cultural, os limites e as potencialidades dos sistemas de interação social. (LÉVI-STRAUSS, 1987, p. 12).

10 Conforme esclarece Burity, o processo de significação assume, no âmbito da teoria do discurso laclauniana, o sentido de articulação entre um significante e um significado. (BURITY, 2014, p. 64).

11 Considerado o locus classicus da tradição pós-estruturalista, o ensaio derridiano "A Estrutura, o Signo e o Jogo no discurso das Ciências Humanas" abriga aquelas que atualmente são consideradas as duas principais objeções à perspectiva teórica estruturalista: a primeira, denominada de hipótese clássica, refere-se ao fato de que todo esforço teórico de totalização do significado de um campo fracassa diante das infi nitas possibilidades empíricas de reconfiguração dos sentidos que lhe são constitutivos; a segunda objeção, intitulada hipótese pós-clássica, parte da pressuposição de que a impossibilidade de totalização do significado de um campo deriva não da existência de múltiplas e concorrentes possibilidades de conceituação, mas sim da constatação de que neste campo há uma falta fundamental, não negativa, mas produtiva, que torna assim possível a existência de múltiplas tentativas de significação/totalização desse campo. (MARCHART, 2007, p. 
considerada um lugar privilegiado na estrutura e passa a ser percebida como uma função estruturante, que pode ser realizada por qualquer elemento/signo capaz de reivindicar para si a aptidão de ordenar, sob o ponto de vista simbólico, o sentido da realidade. ${ }^{12}$ Se as coisas são assim, caberia então indagar: se a realidade enquanto tal não pode ser considerada um dado positivo cujo sentido é determinado a priori, qual é o topoi que abriga o jogo de substituições (retóricas) que permite a sua significação? A resposta nos é apresentada pela noção de discurso.

Para Laclau, a noção de discurso, além de designar um complexo relacional de significantes, representa também "o campo de uma ontologia geral, de uma reflexão do ser enquanto ser". ${ }^{13}$ No entendimento do autor, a incorporação da metáfora do Abgrund ${ }^{14}$ ao pensamento antimetafísico heideggeriano ${ }^{15}$ permitiu o alargamento da noção para além

15; DERRIDA, 2014, p. 421).

12 DERRIDA, 2014, p. 423.

13 LACLAU, 2014, p. 207.

14 Laclau recorda que a metáfora do Abgrund (abismo) reflete, no interior das reflexões heideggerianas sobre a essência dos seres (entes), alude à ideia de que o solo que serve de fundamento, que representa o marco zero de todo e qualquer processo de significação do ser enquanto ser, também é um abismo: "or, to be more precise, the abyss itself is the ground". (LACLAU, 2014, p. 118). A identificação deste abismo fundamental que habita o processo de significação do ser não quer dizer - como recorda Laclau - que não há fundamento algum a amparar as identidades que se manifestam no plano (ôntico) das práticas sociais, mas sim que esse fundamento que lhes serve de base é, ele próprio, precário e contingente, não possuindo, destarte, um sentido último e transcendental, alheio, pois, aos discursos que buscam representar-lhe. Para melhor ilustrar o argumento caberia traçar um paralelo entre a metáfora heideggariana do Abgrund e a noção derridina do "descentramento" (DERRIDA, 2014), afinal de contas, em ambos os casos, o que está em jogo é a visibilização dessa falta/ausência irredutível que habita o processo de significação e que impede a sua cristalização em torno de sentidos últimos, absolutos.

15 LACLAU, 2014, p. 207. 
daquela compreensão que lhe apresenta como uma ontologia regional fundada em categorias linguísticas relacionadas às áreas da fala e da escrita. ${ }^{16}$

Deste modo, para Laclau, pensar sobre o discurso é refletir sobre o "território primário de construção da objetividade enquanto tal". ${ }^{17}$ Mas o que essa intricada assertiva pretende comunicar? Muito objetivamente: que é no campo da interação social, das relações simbólico-discursivas mediadas pela linguagem, que a realidade experimentada pelos sujeitos é construída. No entendimento do autor, portanto, "relação" e "objetividade" são sinônimos, vez que "os elementos [articulados pelo discurso] não preexistem ao complexo relacional, mas se constituem através dele" ${ }^{18}$ No entanto, tal compreensão ainda hoje é objeto de várias críticas, já que em uma primeira (e apressada) leitura corre-se o risco de supor que o autor está a referendar uma interpretação idealista ${ }^{19} \mathrm{e}$, no limite, relativista. ${ }^{20}$ Mas as coisas não são assim:

O fato de que todo objeto é constituído como objeto de discurso não tem nada a ver com a existência de um mundo externo ao pen-

16 LACLAU, 2013, p. 116.

17 LACLAU, 2013, p. 116.

18 LACLAU, 2013, p. 116.

19 De acordo com Laclau, a teoria filosófica do idealismo parte da pressuposição de "a natureza dos [...] objetos é idêntica à representação mental que o sujeito projeta sobre tais objetos". (LACLAU, 1990, p. 106). Em suma, o projeto idealista é caracterizado pela tentativa de reduzir a compreensão da realidade a formulações estritamente racionais e conceituais.

20 Uma importante consideração há de ser aduzida em relação a essa crítica. Em resposta a um dos mais veementes críticos de "Hegemonia e Estratégia Socialista" (2015), Laclau e Mouffe, afirmam que "[o] relativismo é, na verdade, um falso problema. Uma posição 'relativista' seria aquela que afirma que dá no mesmo pensar 'A é B' ou 'a não é B', isto é, que esta é uma discussão ligada ao ser dos objetivos. Como vimos, no entanto, fora de qualquer contexto discursivo os objetos não tem ser; eles apenas têm existência". (LACLAU; MOUFFE, 2015b, p. 42). 
samento, nem com a oposição realismo/idealismo. Um terremoto ou a queda de um tijolo é um evento que certamente existe, no sentido de que ele ocorre aqui e agora, independentemente de minha vontade. Mas, o quanto sua especificidade como objeto é construída em termos de "fenômenos naturais" ou como "expressões da ira de Deus" depende da estruturação de um campo discursivo. O que é negado não é que tais objetos existem externamente ao pensamento, mas, de fato, a afirmação distinta de que eles podem constituir a si mesmos como objetos fora de quaisquer condições discursivas de emergência. ${ }^{21}$

De acordo com Laclau e Mouffe, a vantagem de se enxergar a realidade social como resultado de um processo de construção eminentemente discursivo, reside no fato de que tal assunção permite "um maior alargamento do campo das categorias analíticas que podem dar conta das relações sociais." ${ }^{22}$. Tal afirmativa constitui, a um só tempo, a pressuposição mais elementar e a hipótese a ser testada neste artigo, sobretudo em razão da nossa tentativa de perscrutar o potencial heurístico das figuras da retórica (tropos) para a análise dos discursos relacionados à questão criminal, notadamente da atividade parlamentar vinculada à Lei dos Crimes Hediondos. ${ }^{23}$

Como bem observa Burity, ao atribuir à noção de discurso o status de horizonte teórico-ontológico, ao definir a noção de discurso como topoi que abriga o (interminável) processo de significação do ser, do social, e, mais importantemente, do político ${ }^{24}$, a teoria laclauniana nos convida

21 LACLAU; MOUFFE, 2015, p. 181.

22 LACLAU; MOUFFE, 2015, p. 184.

23 Porque a Lei dos Crimes Hediondos ocupa lugar de destaque nessa análise? Muito simplesmente por que comungamos do entendimento de que este diploma legislativo, mais do que qualquer outro, "representa o marco simbólico do ingresso do Brasil no cenário internacional do grande encarceramento" (CARVALHO, 2015, p. 631).

24 Para Mouffe, sobretudo, há uma clara distinção entre os objetos de estudo 
a abdicarmos deste clássico entendimento assentado pela teoria social que, ainda hoje, produz análises voltadas à explicitação da "tensão, se não uma relação de oposição, que se estabelece entre a ideia de realidade objetiva e uma dimensão de produção de sentido, a qual se crê acrescentar-se sobre a realidade objetiva e, com muita frequência, deformá-la, em função de interesses ou perspectivas particulares" ${ }^{25}$

A síntese formulada por Burity expressa, com absoluta precisão, a pragmática, isto é, os usos comumente atribuídos à noção de retórica no debate político-criminal. Para ilustrar melhor o argumento, propomos colacionar, abaixo, alguns exemplos que demonstram a operacionalização do conceito no interior dos debates travados acerca do fenômeno que se convencionou chamar de populismo penal.

Em estudo dedicado à análise das justificativas apresentadas pelos membros do Congresso Nacional para a edição de leis penais, Luís Wanderley Gazoto veicula a seguinte

da 'teoria política' e da 'ciência política'. (MOUFFE, 2005, p. 9) Tal distinção, consubstanciada na diferenciação entre os conceitos de 'político' e 'política', teve os seus primeiros traços extraídos de obra de Carl Schmitt (SCHMITT, 2007, p. 26), tendo passado, contudo, a ser mais sistematicamente invocada a partir da publicação do ensaio "The Political Paradox" (1957), de Paul Ricoeur. Acerca desta distinção, Oliver Marchart (2007) defende que qualquer análise fundada na perspectiva teórica pós-estruturalista (pósfundacionalista) deve interpelar os processos (discursivos) de construção da realidade a partir de uma dúplice perspectiva: de um lado, a partir da análise da dimensão (ontológica) do político ("the political”), que abrigaria o momento de instituição da sociedade, e, consequentemente, o conjunto de reflexões acerca dos termos que constituem os antagonismos/conflitos cuja enunciação precede e ao mesmo tempo justifica a atribuição de um sentido positivo, relativamente estável, a ideias tais como "coesão social”, "ordem", "comunidade" etc.; de outro, a partir do estudo da dimensão (ôntica) da política ("politics"), que conglobaria o conjunto de práticas e instituições específicas, vale dizer, contextualmente situadas, pensadas para manter ou contestar aquelas pressuposições mais elementares que habitam a dimensão 'do político'. (MARCHART, 2007, p. 8).

25 BURITY, 2014, p. 62. 
conclusão: "é comum, nas exposições de motivos, o apelo exagerado, puramente retórico, do valor ético-moral da proteção estatal ao interesse em questão, mas sem nenhuma referência a critérios de proporcionalidade" ${ }^{\prime 26}$

Avaliando o impacto da filiação dos discursos judiciais àquilo que chamou de populismo penal midiático, Luiz Flávio Gomes observa que:

[...] na medida em que a Justiça começa a se comunicar diretamente com a opinião pública, valendo-se da mídia, ganham notoriedade tanto os anseios populares de justiça (cadeia para todo mundo, prisão preventiva imediata, recolhimento sem demora dos passaportes dos condenados, fim dos recursos - ignorem a justiça internacional) como a preocupação de se usar uma retórica populista, bem mais compreensível pelo 'povão' ('réus bandidos', 'políticos bandoleiros', 'a pena não pode ficar barata', 'o sistema penal brasileiro é frouxo', 'os juízes são flexíveis', 'Vossa Excelência advoga para o réu?', 'no Brasil o rico não vai para a cadeia' etc.). ${ }^{27}$

O criminólogo John Pratt, por sua vez, argumentará em relação às dimensões populistas das tendências político-criminais contemporâneas:

The essential point, though, is that despite subsequent policy differences, politicians voicing the slogans associated with this rhetoric which has travelled around the modern world - 'Life means Life', 'Three Strikes', 'Zero Tolerance' and so on - are sowing the seeds for the growth of penal populism in their country, even if its subsequent harvest is likely to differ in shape and form. ${ }^{28}$

A comparação das análises revela que os respectivos autores operam, indistintamente, a partir de uma mesma concepção de retórica, uma concepção que se ancora na ideia segundo a qual o conceito ilustra um tipo peculiar de

26 GAZOTO, 2010, p. 282.

27 GOMES, 2013, p. 14.

28 PRATT, 2007, p. 92. 
discurso constituído fundamentalmente por sofismas, cujo objetivo imediato é a manipulação inescrupulosa de uma determinada realidade ${ }^{29}$, através da falsificação do verdadeiro significado dos significantes mobilizados pelo orador, pelo autor do discurso. ${ }^{30}$ Em relação a tal concepção, Laclau e Mouffe opõem o seguinte entendimento:

Sinonímia, metonímia, metáfora, não são formas de pensamento que acresçam um sentido secundário a um sentido primário, constitutivo da literalidade das relações sociais; ao invés disso, elas são parte do próprio terreno primário no qual o social é constituído. ${ }^{31}$

Neste sentido, para Laclau e Mouffe a retórica e suas figuras representam, no limite, movimentos semânticos elementares e essenciais para a construção de sentidos mobilizados por uma determinada ordem discursiva. A sua compreensão teria, portanto, o condão de revelar não as estratégias de um orador que busca conquistar a atenção e o coração da sua audiência, mas sim a própria "anatomia do mundo social", como determinados discursos operam deslocamentos semânticos com o propósito, por exemplo, de tornar hegemônica ${ }^{32}$, através de sinédoques, uma determina-

29 Neste sentido, caberia lembrar que para Kant a retórica, como epifenômeno da oratória, representaria da arte de um homem "servir-se das fraquezas de outros homens para seus propósitos", motivo pelo qual ela, a despeito do caráter e das reais intenções dos oradores, não poderia ser "digna de nenhum apreço". (KANT, 2002, p. 172, nota ao §53)

30 Breve, porém reveladora, passagem denota como Laclau e Mouffe concebem a ideia de "verdade" em relação ao estudo das relações e processos sociais de significação: "a 'verdade', factual ou outra, sobre o ser dos objetos é coinstituída dentro de um contexto teórico e discursivo e a ideia de uma verdade fora de todos os contextos é simplesmente disparatada". (LACLAU; MOUFFE, 2015b, p. 44)

31 LACLAU; MOUFFE, 2015, p. 184.

32 Mendonça e Rodrigues lembram que a expressão hegemonia, no pensamento de Ernesto Laclau, designa, muito simplesmente, "a tentativa de constituição de uma relação de ordem [...]. Uma relação em que uma determinada 
da concepção sobre a sociedade ${ }^{33}$, seus atores e instituições. ${ }^{34}$

Com esses registros acreditamos ter esclarecido suficientemente os pressupostos do presente artigo. A seguir, buscamos perscrutar o valor heurístico da Retórica e das suas figuras (tropos) para a formulação de uma análise (crítica) da discursividade parlamentar, sobretudo a de corte punitivista.

\section{A plenitude presentificada no vazio semântico do significante "hediondo"}

Para aqueles que interpelam a questão da Retórica a partir das perspectivas aristotélica ${ }^{35}$ e platônica $^{36}$, pode pa-

identidade, em um determinado contexto histórico, de forma precária e contingente, passa a representar múltiplos elementos.". (MENDONÇA; RODRIGUES, 2014, p. 53).

33 No ponto, Laclau é preciso: “[...] numa relação hegemônica, uma diferença particular assume a representação de uma totalidade que a excede. Isso confere uma clara centralidade a uma figura particular no arsenal da retórica clássica: a sinédoque (a parte que representa o todo)". (LACLAU, 2013, p. 212). No entendimento do autor, a sinédoque representa não um embuste persuasivo, mas sim uma figura retórica dotada de uma função ontológica específica, qual seja, representar um deslocamento semântico cujo propósito é guindar um determinado discurso ou significante à condição de elemento representativo do todo, um deslocamento que, se exitoso, transformará (metaforicamente) esse discurso ou significante no nome que do todo. Ilustremos o argumento com um exemplo político-criminal: a função ontológica da sinédoque transparece sempre que o "povo" é invocado no interior dos discursos políticos-criminais (institucionais ou não) que buscam legitimar a opção pela intervenção jurídico-penal, sob a justificativa de atender aos anseios do "povo".

34 LACLAU, 2013, p. 172.

35 Para Aristóteles, a retórica consiste da "capacidade de descobrir o que é adequado a cada caso com o fim de persuadir.". (ARISTÓTELES, 2005, livro I, cap. 2. p. 156).

36 Platão explicita sua primeira compreensão acerca da "arte retórica" no diálogo estabelecido entre Sócrates e Górgias, mais especificamente no ponto em que o primeiro diz ao segundo: “Ficaste sabendo, agora, o que penso a respeito da retórica: é a antítese para a alma do que a cozinha é para 
recer no mínimo equivocado atribuir a ela e às suas figuras de linguagem (tropos) a qualidade de instrumentos úteis para a realização de análises discursivas críticas filiadas à corrente do pensamento pós-estruturalista. Não seria uma análise discursiva fundada em termos retóricos um exercício meramente estético, desprovido, pois, de qualquer tom de cientificidade? Uma colocação deste gênero somente poderia ser considerada legítima se nos contentássemos com este entendimento que equipara a Retórica à arte de bem-dizer, à arte da ornamentação "dos discursos por meio de estratégias argumentativas e figuras de linguagem que os tornam mais atraentes e 'coloridos'" . ${ }^{37}$ Não é este, contudo, o entendimento que nos ampara.

Conforme argumentado outrora, subjaz a esse tipo de interpretação uma pressuposição de natureza ontológica que merece ser colocada em xeque, a saber: de que a realidade enquanto tal possuiria dois níveis de significação: um nível primário, que refletiria o sentido literal das coisas mesmas, que, por sua vez, poderia ser inferido de uma constelação de traços descritivos (extradiscursivos) que salvaguardariam o significado verdadeiro da coisa de qualquer voluntarismo hermenêutico; um nível secundário, onde a literalidade daria lugar à figuração, onde a reflexão sobre essência seria precedida pelo estudo da aparência, onde, finalmente, a busca pela verdade cederia espaço ao ardil, ao engodo persuasivo. A Retórica e as suas figuras, na esteira deste entendimento, situar-se-iam no nível secundário, motivo pelo qual seu escopo, a rigor, seria distorcer - e assim obscurecer - a

o corpo.". (PLATÃO, 2002, p. 245). Para uma leitura mais aprofundada do processo da dignificação da retórica no âmbito dos diálogos platônicos, algo verificado sobretudo no Fedro (Fedão), conferir: DAMASCENO; MEGALE, 2008, p. 339-344.

37 REIS, 2014, p. 76. 
suposta transparência dos sentidos que constituem aquele primeiro nível representacional, onde seria possível encontrar, conforme lembrado por Correas (2013), o fundamento (dogmático) da autoridade científica do Direito (positivista ${ }^{38}$ ).

Desnecessário enfatizar o fato de que a incorporação dessa distinção entre níveis de representação parte de uma pressuposição que - em função do referencial teórico que anima o presente estudo - foi por nós, de início, descartada, qual seja, a de que existiriam verdades metafísicas, objetos e fenômenos (sociais e políticos) dotados de um significado transcendental, universalmente válido, constituído extradiscursivamente e imune a qualquer tipo de injunção histórica ou contextual. ${ }^{39}$ Para os parlamentares, não funciona bem assim...

Com esses esclarecimentos é chegado o momento de justificar o empreendimento teórico ora proposto, ressaltando a sua contribuição prática para o estabelecimento de um estudo empírico-retórico dos discursos parlamentares de corte punitivista. ${ }^{40}$

Comecemos, pois, pela realização de uma análise mais geral sobre o próprio processo de atribuição de sentido ao significante "hediondo", algo que reputamos central para toda e qualquer análise que pretenda abordar de forma crítica, isto é, não meramente descritiva, os discursos que

38 Cf. CORREAS, 2013, p. 80

39 MARCHART, 2007, p. 29.

40 O nome ora atribuído a tal abordagem encontra sua inspiração mais imediata no estudo realizado por Reis (2014) e intitulado "Análise empírico-retórica do discurso constitucional: uma contribuição metodológica à pesquisa de base em direito". Embora distintas no tocante ao tipo de discurso perscrutado (v.g. Reis opta pela análise da discursividade judicial, nós, por outro lado, pela análise da discursividade parlamentar), ambas as abordagens convergem na opção pela exploração do potencial heurístico da Retórica e das suas figuras de linguagem em detrimento da explicitação (tautológica) dos rótulos pejorativos que lhe são comumente atribuídos. 
gravitam em torno da normatividade da Lei Federal $n^{\circ}$ 8.072/1990.

A rigor, o significante "hediondo" designa, enquanto sinônimo, algo ou alguém que se reputa sórdido, ignóbil, vil, repugnante etc. Embora o significado da expressão pareça ser de fácil compreensão pelo senso comum (Será? Hediondo é fácil compreender junto ao senso comum?), o mesmo não pode se dizer em relação ao seu sentido jurídico.

Sabe-se, sobretudo em função das investigações conduzidas por Alberto Silva Franco (2000), que o legislador brasileiro, desde a formação da Assembleia Nacional Constituinte de $1988^{41}$ até os dias atuais, jamais demonstrou preocupação ${ }^{42}$ com relação à definição das circunstâncias/condições que permitiriam/justificariam atribuir a uma determinada conduta a qualidade de "hedionda". ${ }^{43}$

41 Estranha às teorias criminológicas, jurídico-penais e político-criminais do final da década de oitenta, a expressão "crimes hediondos" "surgiu na Assembleia Nacional Constituinte no momento em que dois grupos políticos antagônicos propuseram obrigações constitucionais de criminalizar determinadas condutas. Pela esquerda, propôs a criminalização de manifestações de racismo, de ações contra o Estado Democrático de Direito e da tortura. Pela direita, propôs-se que as mesmas cláusulas duras fossem sujeitadas a luta revolucionária, sob a designação de terrorismo, ao tráfico ilícito de entorpecentes e a outros crimes considerados particularmente graves.". (PAIVA, 2009, p. 80).

42 Interessante observar que a definição jurídica da expressão parece importar, atualmente, tanto quanto importava a época dos debates que culminaram na promulgação da Constituição Federal de 1989. Neste sentido, lembranos Paiva (2009), ao ser confrontado com críticas relacionadas à imprecisão semântica da expressão, o constituinte Amaral Neto defendeu a permanência do termo "hediondo" na versão final do texto constitucional por meio do seguinte argumento: "O Código Penal que faça isso depois de constar de todo o seu corpo, definindo o que é crime hediondo. Se não fizermos isso, estaremos deixando os criminosos mais vis, mais monstruosos à disposição de uma lei que lhes dará os mesmos direitos de um ladrão de galinha.". (PAIVA, 2009, p. 81).

43 FRANCO, 2000, p. 93. 
Se as coisas são assim, ou seja, se a natureza equívoca $^{44}$ do significante em questão não parece perturbar o legislador ${ }^{45}$, é porque o vácuo de significação resultante da indefinição jurídica do termo parece ser, em larga medida, funcional.

Tal funcionalidade compreende, a um só tempo, tanto a possibilidade de se promover, indiscriminadamente, totalizações metafóricas ${ }^{46}$ - que dão azo ao fenômeno que convencionou chamar de direito penal simbólico ${ }^{47}$ - como

44 Desafiando abertamente a própria lógica expressa pelo princípio da legalidade estrita, e larga medida representado no aforismo lex certa, postulado que ressalta a ilegitimidade democrática de prescrições jurídico-penais vagas e indeterminadas. (FERRAJOLI, 2010, p. 346).

45 Interessante notar que como a tarefa de dizer o "hediondo", constitui, graças ao texto constitucional (art. $5^{\circ}$, inciso XLIII), um exercício hermenêutico eminentemente tautológico. O "hediondo" é, por assim dizer, o que a lei diz ser. A circularidade do argumento engendrado pela aludida disposição constitucional lembra, por certo, a natureza fora-da-lei do fundamento da própria ordem legal. No ponto, Žižek ilustra eu argumento rememorando a admoestação realizada por Kant a todos aqueles que buscam pelo fundamento (autoevidente?) da Lei: “A violência ilegítima em que se sustenta a lei deve ser dissimulada a qualquer preço, porque essa dissimulação é condição positiva do funcionamento da lei [...]”. (ŽIŽEK, 1992, p. 64).

46 Teremos a oportunidade de discorrer mais detalhadamente acerca deste conceito. Por ora, basta referir que ele ilustra um tipo de deslocamento semântico que se encontra implicado naquilo que Laclau e Mouffe chamaram de 'lógica da equivalência', conceito que, por sua vez, designa um momento particular no processo construção do caráter hegemônico de uma determinada ordem discursiva (LACLAU; MOUFFE, 2015, p. 206), no qual as relações de contiguidade (metonímia) e analogia (metáfora) que tornam equivalentes os termos articulados pelo discurso dão lugar a uma relação de pura identidade. Em suma, totalizar metaforicamente significa, muito simplesmente, representar como (logicamente) necessária, isto é, como não contingente, a relação semântica que se estabelece entre dois ou mais termos mobilizados em mesmo contexto discursivo.

47 Remetemos o leitor, no ponto, à definição formulada por Batista, Zaffaroni, Alagia e Slokar: "Para a lei penal não se reconhece outra eficácia senão a de tranquilizar a opinião pública, ou seja, um efeito simbólico, com o qual se desemboca em um Direito Penal de risco simbólico, ou seja, os riscos não se neutralizariam, mas ao induzir as pessoas a acreditarem que eles não 
a possibilidade de revitalização da ideia de representação democrática. Embora a comprovação dessas hipóteses não constitua propriamente o objetivo deste artigo, ambas merecem alguma problematização, sobretudo na medida em que ilustram a pertinência do empreendimento teórico defendido neste artigo.

No que diz respeito à primeira funcionalidade, é interessante observar que o que falta ao "hediondo" em termos de objetividade semântica, sobra-lhe em termos daquilo que, na falta de melhor termo, chamaremos de "potencial metafórico ficcional". ${ }^{48}$ Neste sentido, veremos em detalhes ao longo do próximo tópico, como a mera alusão (metonímica) ao caráter "hediondo" de uma determinada conduta, já é suficiente para que a necessidade de intensificação e ampliação das hipóteses de intervenção jurídico-penal ganhe ares de autoevidência, justificando, assim, o manejo de metáforas tipicamente ficcionais, tais como aquelas que figuram na exposição de motivos do $\mathrm{PLC}^{49} \mathrm{n}^{\mathrm{o}}$ 846/2015,

existem, abranda-se a ansiedade ou, mais claramente, mente-se, dando lugar a um Direito Penal promocional, que acaba se convertendo em um mero difusor de ideologia.". (BATISTA; ZAFFARONI; ALAGIA; SLOKAR, 2011, p. 631).

48 Partindo da premissa de que nunca poderemos alcançar algo tal como a (R)ealidade, Zaffaroni argumenta que a discursividade jurídico-penal comporta dois tipos de deslocamentos semânticos de tipo metafórico: se de um lado o recurso à metáfora pode ser representado como uma tentativa, genuinamente heurística, de relacionar sistemas de referências distintos com vistas à elaboração de uma compreensão mais aprofundada sobre o objeto/fenômeno analisado; de outro, o recurso à metáfora também pode dar azo ao estabelecimento de relações de analogia arbitrárias, calcadas, pois, unicamente, em ficções sem qualquer correspondência com a realidade social: “a primeira atitude é a de quem, diante de uma massa pletórica de realidade, comporta-se com prudência, enquanto a segunda atitude é a de quem, diante de um vazio da realidade, preenche-o com sua imaginação.". (ZAFFARONI, 2010, p. 48).

49 Projeto de Lei de iniciativa da Câmara dos Deputados. 
cuja aprovação resultou na promulgação da Lei Federal $n^{\circ}$ 13.142/2015, a qual integra ao rol dos crimes hediondos os crimes de lesão corporal dolosa de natureza gravíssima e de lesão corporal seguida de morte, quando praticados contra agentes de segurança pública:

A criação de causa de aumento de pena para este tipo de crime é crucial para fortalecer o Estado Democrático de Direito e as instituições legalmente constituídas para combater o crime, especialmente o organizado, o qual planeja gerar pânico e descontrole social, quando um ator do combate à criminalidade é vítima de homicídio tentado ou consumado. ${ }^{50}$

O tipo de metáfora ficcional invocada pelo autor da justificativa transcrita subjaz a essa já conhecida dicotomia: ou a intensificação da intervenção jurídico-penal, ou a pura e simples desintegração dos laços sociais que garantem a vida em comunidade. Um cenário que muito se assemelha àquele representado pela mais célebre das metáforas da teoria política moderna: o estado de natureza hobbesiano. ${ }^{51}$

Esse tipo de deslocamento metafórico - que, não sendo exclusivo dos discursos que gravitam em torno da normatividade da Lei dos Crimes Hediondos, vem, a rigor, dando a tônica das iniciativas legislativas levadas a cabo em matéria de direito penal nas últimas décadas - pode ser mais claramente representado pela afirmação do caráter (logicamente) necessário dessa relação (de identidade semântica) que se estabelece entre as ideias de "tutela jurídico-penal" e "resposta institucional à conflitividade social", uma relação que

50 BRASIL, 2015, p. 1-2.

51 A força estruturante da alusão metafórica pode ser vislumbrada, igualmente, no campo dos discursos sobre a questão criminal. Basta reconhecermos que a mobilização "eficaz" do significante "segurança", neste contexto discursivo, pressupõe a invocação de metáforas tais como a "ordem pública", uma fantasia ideológica que, como lembra Žižek, não busca representar falsamente a realidade, mas sim garantir as condições necessárias para a estruturação dos seus próprios limites. (ŽIŽEK, 1996, p. 316). 
evidencia o caráter hegemônico do discurso de intervenção jurídico-penal.

Outro tipo de totalização metafórica que pode ser inferida da análise da proposição legislativa acima transcrita emerge da seguinte problematização: ao tutelar de forma diferenciada a integridade física dos agentes de segurança, o legislador brasileiro perdeu uma excelente oportunidade para reconhecer e, assim, transformar o outro lado da realidade que deu ensejo à edição da Lei Federal n ${ }^{0}$ 13.142/2015: a violência institucional protagonizada pelos próprios agentes de segurança. Seguindo por essa linha argumentativa, torna-se inevitável indagar: afinal, o que representam, em termos político-criminais, as hipóteses normativas engendradas pela Lei Federal n ${ }^{\circ}$ 13.142/2015 num contexto de discussão caracterizado, sobretudo, pela gradual intensificação dos discursos punitivos e pelo crescimento, esse sim exponencial, da letalidade das forças policiais brasileiras? ${ }^{52}$ Esse tipo de questionamento sugere, com efeito, a necessidade de realizarmos uma segunda reflexão, ainda mais decisiva: porventura a morte de um cidadão (esteja ele envolvido ou não com o exercício de atividades ilícitas) em virtude do emprego excessivo de força por parte dos agentes de segurança pública, também não representaria um fato sob qualquer perspectiva aviltante, merecedor, pois, da tutela prometida pela Lei dos Crimes Hediondos? O que interessa reter de ambos os questionamentos é o seguinte: a apropriação en-

52 No relatório anual da Anistia Internacional referente aos anos de 2014 e 2015, a atuação das polícias militares brasileiras foi classificada como "extremamente preocupante". O aumento considerável das mortes de civis durantes a realização de operações de ocupação e segurança, especialmente no estado do Rio de Janeiro, culminou na elaboração de requerimento para que governo federal iniciasse, imediatamente, um plano nacional visando à redução das taxas de homicídio em todo o País. Disponível em: https:// anistia.org.br/wp-content/uploads/2015/02/Web-Informe-2015-03-06-final. pdf. Acesso em: 15 de Outubro de 2015. 
viesada da realidade social pela discursividade parlamentar denota, com alguma clareza, os riscos que derivam desse tipo de totalização metafórica que identifica a hipótese de intervenção jurídico-penal como sendo o único instrumento possível de solução de conflitos sociais.

Outra funcionalidade a ser extraída dessa reflexão acerca das razões que justificam a manutenção deste verdadeiro vácuo de significação - resultante da indefinição jurídica do termo "hediondo" - resta consubstanciada, a nosso ver, na consolidação daquilo que chamaremos de "representatividade democrática exclusivista". 53

Conforme observado por Franco (2000) e Paiva (2009), em momentos de aguda instabilidade político-institucional ou, para seguirmos utilizando o léxico conceitual laclauniano, em momentos de deslocamento ${ }^{54}-$, nos quais o parlamento

53 A expressão inspira-se nas conclusões referendadas pela sociológica Laura Frade em estudo dedicado à análise das representações sociais veiculadas pela discursividade parlamentar ao longo da $52^{\mathrm{a}}$ legislatura do Congresso Nacional acerca da criminalidade. Ao término da pesquisa, a autora conclui que duas pressuposições fundamentam o imaginário dos parlamentares entrevistas relativamente à questão criminal: a primeira dá conta de que para o corpo parlamentar as políticas de segurança pública devem ser baseadas em ações e estratégias preferencialmente repressivas; a segunda, por sua vez, refere-se à ideia de que a criminalidade constitui um fenômeno "fortemente vinculado à pobreza" sendo que a sua existência é tributável exclusivamente à figura de um transgressor que "tem baixa instrução, é doente, indigno de confiança, indisciplinado, pouco humano, desocupado, sujo e inferior". Em suma, as análises referendadas pela autora amparam essa percepção que informa que a própria noção de representatividade política confunde-se, contemporaneamente, com a ideia de que os parlamentares devem legislar proteger a sociedade de um inimigo interno cuja imagem difere largamente daquela que eles próprios fazem acerca de si e acerca e dos cidadãos que alegam representar. (FRADE, 2008, p. 110).

54 O conceito de deslocamento, aplicado aos processos de significação, foi concebido no interior abordagem psicanalítica lacaniana e representa uma espécie de momento limítrofe no qual as dimensões do simbólico e do imaginário são confrontadas pelo Real. Em termos sociopolíticos, a noção em questão alude a uma experiência traumática que marca a ocorrência de 
vê sua legitimidade (pressuposta) questionada a partir dos seus próprios fundamentos, percebe-se que o significante "hediondo" tem sido convocado pelo corpo parlamentar sob o pretexto de reestabelecer, relembrar e redefinir as identidades dos sujeitos imiscuídos neste corte antagônico ${ }^{55}$, que é capaz, em última instância, de estruturar uma ordem político-criminal punitivista.

Neste sentido, revela-se digno de nota o fato de que os

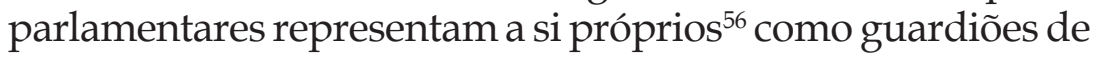
um conjunto de valores sociais permanentemente ameaçados pela criminalidade. ${ }^{57}$ Tal constatação pode ser vislumbrada na análise das justificativas formuladas por ocasião do oferecimento das seguintes proposições legislativas, todas com origem na Câmara dos Deputados: 5.405/90 ${ }^{58}, 4.682 / 98^{59}$ e $846 / 2015^{60}$, respectivamente:

um evento desestruturador que, por sua vez, modifica substancialmente os processos de significação que garantem o caráter hegemônico de uma determinada ordem ou sistema social: "o deslocamento [...] pode ser caracterizado como o momento no qual emerge a sensação de que as coisas não estão nada bem, isto é, de que nada é tão inteligível quanto antes". (GLYNOS e HOWARTH, 2007, p. 143)

55 Partindo da Teoria do Discurso de Laclau e Mouffe, argumentamos em outra ocasião, que o antagonismo retratado pela oposição das identidades "vítimas" (reais ou potenciais) e "criminosos", constitui a pressuposição ideológica fundamental da discursividade parlamentar de corte punitivista.

56 A presente inferência está em consonância com as conclusões referendadas por FRADE (2008).

57 Em estudo dedicado à análise das representações sociais vigentes entre os parlamentares da $52^{\circ}$ legislatura do Congresso Nacional, Laura Frade conclui que a maior parte das proposições legislativas editadas em matéria de direito penal durante o período investigado trata (metaforicamente) o conceito de política criminal como se ele representasse (sinonimicamente) uma agenda de reformas legislativas imbuídas do propósito de ampliar os rigores da intervenção jurídico-penal. (FRADE, 2008, p. 108)

58 Projeto de lei que cuja tramitação deu ensejo à Lei dos Crimes Hediondos.

59 Proposição legislativa que abriga o texto-base da Lei Federal no 9.695/98, que incluiu no rol dos crimes hediondos a hipótese da falsificação de produtos destinados a fins terapêuticos ou medicinais.

60 Projeto de lei cuja aprovação resultou na promulgação da Lei Federal $n^{\circ}$ 
Entendemos, preliminarmente, quanto à proposição, que o Poder Legislativo não poderia perder esta oportunidade para oferecer sua concreta contribuição à legislação penal, tendo em vista, ainda, a natureza dos crimes que vêm abalando e causando indignação e repulsa da sociedade, o resgate do débito de regulamentação do dispositivo constitucional que pede a definição dos crimes hediondos, entre os quais, necessariamente se incluem o sequestro e a extorsão. ${ }^{61}$

A imprensa de todo o país tem divulgado diariamente a prática de um dos crimes mais covardes, mais perversos, contra a população brasileira: a falsificação de remédios. [...] Estamos diante de uma máfia especializada que está praticando um verdadeiro genocídio, exterminando todos os nossos doentes. Este Parlamento não pode permanecer inerte diante dessa barbárie, dessa monstruosidade. ${ }^{62}$

[...] este Projeto vem num momento muito importante da segurança pública do Brasil e da sociedade brasileira. Não seria razoável que esta Casa não se posicionasse no momento em que policiais das diversas forças estão sendo abatidos no Brasil, por enfrentarem o crime, especialmente o crime organizado $[\ldots]{ }^{63}$

Assim, por meio através do apelo ao significante "hediondo", reinventa-se, contemporaneamente, a utilidade política e a legitimidade democrática da intervenção jurídico-penal. O hediondo passa a funcionar como um operador ideológico que, seja como significante-mestre ${ }^{64}$, seja como

13.142/15 que, a seu turno, atribuiu às hipóteses de lesão corporal dolosa de natureza gravíssima e lesão corporal seguida de morte, quando praticadas contra agente de segurança pública a qualidade de crimes hediondos.

61 BRASIL, 1990, p. 38.

62 BRASIL, 1998, p. 4.

63 BRASIL, 2015, p. 1-2.

64 O termo, oriundo da psicanálise lacaniana, nomeia um elemento discursivo particular que, abdicando parcialmente da sua identidade semântica particular, passa a representar, metaforicamente, uma espécie de ponto nodal em torno do qual o discurso ganha unidade e coesão. O significante mestre é, destarte, "a palavra de ordem, o momento do corte histórico e de constituição de uma nova ordenação simbólica do discurso". (LACLAU, 
centro de uma cadeia de significação, ordena simbolicamente o conteúdo dos distintos sentimentos articulados pelos discursos parlamentares de corte criminalizador (medo, insegurança, impunidade etc.).

Acreditamos que este último argumento pode ser mais adequadamente representado na medida em que o relacionamos, retoricamente, à "Alegoria da Persuasão de Pascal", elaborada por Paul de Man e problematizada por Ernesto Laclau no ensaio "The politics of rhetoric" (2014).

De acordo com a síntese apresenta por Laclau, de Man procura refletir ao longo da sua alegoria acerca das particularidades da relação dialética que se estabelece entre os signos "zero" e "um" no interior do sistema numérico. Nessa alegoria, de Man inicia suas reflexões com a seguinte indagação: como poderia o "um", símbolo por excelência da unidade, derivar logicamente de um signo que, por natureza, representa a própria ausência? Dito de outro modo: como o zero, que é radicalmente heterogêneo à ordem do número, pode, ele próprio, funcionar como centro da cadeia de significação representada pelo sistema numérico. Laclau observa que para de Man, na dialética zero/um, o zero encarna, metaforicamente, um sentido radicalmente performativo (figurativo), deixando de representar um lugar vazio para servir como elemento representativo da própria sistematicidade do sistema (numérico). Por esse motivo, para de Man “não poderia haver 'um' sem o 'zero', mas o 'zero' sempre aparece sob o disfarce do 'um', de '(alguma)coisa' 65 . O nome é a metáfora do 'zero'. O zero é sempre chamado de 'um', mesmo quando ele é, efetivamente, inominável". ${ }^{66}$ Comentando essa última passagem, Laclau observará que,

2015, p. 38)

65 No original: "(some)thing” (LACLAU, 2014, p. 83).

66 DE MAN, 1996, p. 59 apud LACLAU, 2014, p. 83. 
sob o ponto de vista simbólico-estrutural, embora o zero seja radicalmente heterogêneo à ordem do número, "essa ordem não pode ser constituída sem que se faça referência ao zero" ${ }^{67}$ Assim, não obstante o zero represente o contrário da unidade, a mera referência à sua existência produz um efeito fundamental de fechamento do sistema (numérico) de significação. A conclusão referendada por Laclau é fundamental para a compreensão do propósito dessa aproximação ora sugerida, entre a noção de discurso, tal como apresentada por Laclau e Mouffe, e o termo hediondo, que, ao menos em sede de hipótese, parece relacionar-se - sob o ponto de vista simbólico - com o sistema jurídico-penal da mesma forma como o zero se relaciona com o sistema numérico na alegoria pascaliana ${ }^{68}$ :

[...] o zero representa um "nada" - mas um "nada" que pertence ao próprio sistema, um "nada" que representa a impossibilidade de um fechamento consistente deste sistema, tudo isso é significado pelo zero; nesse sentido, paradoxalmente, o zero, como um lugar vazio, torna-se o significante da plenitude, da sistematicidade do sistema enquanto tal, daquilo que lhe falta [...] tal como sucede no caso do zero pascaliano, nos defrontamos com um objeto que é ao mesmo tempo impossível e necessário. Impossível na medida em que representa um lugar vazio no interior da estrutura; necessário porquanto é um "nada" que, tendo acesso ao campo da representação, produzirá efeitos estruturantes. ${ }^{69}$

67 LACLAU, 2014, p. 84.

68 Se o "zero" da alegoria pascaliana representa "algo" radicalmente heterogêneo a ordem do número, cogitamos, numa aproximação, se os juízos (morais) de reprovabilidade que fundamentam, sob o ponto de vista político-criminal, a Lei dos Crimes Hediondos, não estariam a representar, eles próprios, elementos radicalmente heterogêneos se comparados a uma ordem jurídico-penal laica, não calcada apenas em ideais de inspiração retributivista.

69 Tradução livre. LACLAU, 2014, pp. 84-85. 
Essa transposição fundamentalmente catacrética ${ }^{70}$, onde o "nada" adquire o sentido de "algo", para além de expressar um dos passos fundamentais a ser dado na direção desse momento político decisivo chamado por Laclau de "hegemonia", retrata, agora de acordo com o nosso entendimento, as lógicas que envolvem e justificam, contemporaneamente, o apelo intermitente, porém sempre recorrente, ao "hediondo" no interior dos discursos parlamentares que tratam da questão criminal.

É que o "hediondo", à maneira das justificativas transcritas anteriormente, pode ser lido muito claramente como um objeto (discursivo) impossível, porém necessário: impossível na medida em que ele próprio carece - como visto - de um significado jurídico; necessário porque, apesar da sua vacuidade semântica, ainda sim é capaz de produzir efeitos estruturais em relação à conservação dessa ordem hegemônica traduzida na representação da intervenção jurídico-penal como uma espécie de resposta institucional autoevidente e invariavelmente necessária aos conflitos sociais.

Aí reside aquilo que chamaremos de vocação estrutural do significante "hediondo", que serve à discursividade parlamentar como uma espécie de significante-mestre cuja enunciação permite aos membros do Parlamento ampliar - a despeito de qualquer consideração sobre as implicações socioeconômicas que resultam deste tipo de empreendimento legislativo - a margem de manobra e intensidade do poder punitivo, recrudescendo sanções e procedimentos sob o pretexto de reafirmar, para além das já conhecidas ideias de retribuição, dissuasão e reabilitação, a utilidade do próprio

70 De acordo com Laclau a catacrese representa "um termo figurativo que não pode ser substituído por um termo literal (por exemplo, quando falamos da 'perna' da cadeira)" (LACLAU, 2013, p. 121). Quer-nos parecer que a construção do 'hediondo', dado o atual contexto jurídico-normativo, é, para além de metafórica, catacrética. 
modelo democrático representativo e, consequentemente, a legitimidade da figura do político profissional.

Efetivamente, diante deste cenário caberia cogitar se a ordenação dessa vacuidade semântica não constitui uma utopia, já que a realização desse tipo de controle, mediante o estabelecimento de limites semânticos naturalmente pressupõe o delineamento de uma espécie de barreira de contenção em relação ao exercício do hoje plenipotenciário poder atribuído ao legislador ordinário relativamente à possibilidade de escolha das infrações penais que merecem ser predicadas pelo adjetivo "hediondo".

\section{Sinédoque e catacrese: construindo o "povo", significando o "hediondo"}

É chegado, enfim, o momento de analisarmos os discursos parlamentares que ensejaram algumas proposições legislativas cuja aprovação culminou na reforma da Lei dos Crimes Hediondos.

Se no tópico anterior a metonímia veio ao nosso auxílio, neste tópico lançaremos mão das figuras da sinédoque e da catacrese. Teremos a oportunidade de demonstrar que, enquanto a primeira figura representa o tipo de substituição que rege o processo de construção das identidades/vontades coletivas mobilizadas no interior dos discursos analisados, a segunda ilustra a tentativa de se superar a instabilidade gerada pela vacuidade semântica que resulta da indeterminação jurídica do termo "hediondo", um significante que, em função da sua vocação catacrética, pode, desde logo, ser definido, em termos laclaunianos, como um significante vazio. $^{71}$

71 De acordo com Laclau um significante vazio não representa apenas um 
Comecemos por esclarecer o tipo de deslocamento semântico ilustrado pelos dois operadores retóricos em perspectiva; logo após, explicitaremos as funções ontológicas por eles desempenhadas no interior dos discursos parlamentares analisados.

A sinédoque, isto é, o movimento de substituição da parte pelo todo (pars per toto) ou, inversamente, do todo pela parte (totum pro parte), denota uma "relação entre dois significantes baseada na generalização ou particularização" dos seus respectivos significados. ${ }^{72}$ Ilustrando o funcionamento deste operador retórico nos discursos jurídicos, Machado (2013) argumenta, lançando mão do ferramental analítico laclauniano, que os movimentos de substituição propiciados pela sinédoque são representações retóricas do processo de construção do caráter hegemônico de um determinado discurso sobre "O Direito", uma realidade cujo significado só pode ser estabelecido ou, melhor dizendo, estabilizado, "pela operação de sinédoque de chamar a justiça, por exemplo, de 'imparcialidade', ou de 'correção moral'" .73

Como observado por Machado (2013), em termos políticos, a sinédoque ilustra o momento da hegemonia, isto é, o momento em que um elemento particular, sem abrir mão da sua particularidade, passa a representar a ideia de um todo

significante sem significado. Tal entendimento ilustra, para o politólogo argentino, uma forma inadequada de abordar a tese lacaniana da autonomia do significante frente ao significado. Para Laclau, um significante sem significado é apenas um "ruído" incomunicável. Quando faz alusão a noção de significante vazio, Laclau tem em mente algo diferente: "[...] quando falamos de 'significantes vazios' [...] queremos dizer que existe um lugar, no sistema de significação, é que constitutivamente irrepresentável. Nesse sentido ele permanece vazio, mas este é um vazio que pode ser significado, pois estamos lidando com um vazio no interior da significação". (LACLAU, 2013, p. 166).

72 DUNKER; ASSADI, 2004, p. 93.

73 MACHADO, 2013, p. 951. 
que lhe é incomensurável. Essa parte guindada à condição de todo no debate parlamentar realizado em torno da Lei dos Crimes Hediondos está estampada, a nosso ver, nas identidades políticas coletivas (sociedade, povo brasileiro etc.) invocadas nas exposições de motivos das proposições legislativas analisadas a seguir.

Iniciemos pela transcrição de parte da exposição de motivos do PLC $n^{\circ}$ 5.405/1990, que, tendo substituído o PLS n ${ }^{\circ}$ 50/1990, culminou na aprovação da própria Lei dos Crimes Hediondos:

Entendemos, preliminarmente, quanto à proposição, que o Poder Legislativo não poderia perder esta oportunidade para oferecer sua concreta contribuição à legislação penal, tendo em vista, ainda, a natureza dos crimes que vêm abalando e causando indignação e repulsa da sociedade. ${ }^{74}$

Abaixo colacionamos parte da exposição de motivos constante do PLC n ${ }^{\circ} 4.146 / 1993$, cuja aprovação resultou na promulgação da Lei Federal no 8.930/1994, que, por sua vez, terminou chancelando a inclusão de inúmeras figuras delitivas no rol dos crimes hediondos:

A sociedade brasileira clama, há muito, pela reforma da legislação penal que se mostra inadequada à realidade dos tempos atuais, em que dia a dia cresce a violência contra a pessoa. Escusado ressaltar que tais episódios de selvageria e hedionda violência, sem uma enérgica reação dos poderes públicos constituídos, não só vulneram o sentimento cristão do povo brasileiro, mas contribuem sobremodo para macular a imagem do nosso País perante o conserto das nações civilizadas que repugna toda a sorte de impunidade. $^{75}$

Logo abaixo, excerto extraído da exposição de motivos do PLC n ${ }^{\circ} 4.628 / 1998$, cuja aprovação deu ensejo à promul-

74 BRASIL, 1990, p. 38.

75 BRASIL, 1994, pp. 7-8. 
gação da Lei Federal n ${ }^{\circ}$ 9.695/98, que acrescentou ao rol dos crimes hediondos o delito de falsificação de produtos destinados a fins terapêuticos ou medicinais: "a imprensa de todo o país tem divulgado diariamente a prática de um dos crimes mais covardes, mais perversos, contra a população brasileira: a falsificação de remédios" ${ }^{76}$

Por fim, cabe proceder à transcrição de parte das justificativas apresentadas no PLC n ${ }^{\circ} 846 / 2015$, cuja aprovação deu ensejo à promulgação da Lei Federal n ${ }^{\circ} 13.142 / 2015$, que, como já observado, incluiu no rol dos crimes hediondos os delitos de lesão corporal dolosa, de natureza gravíssima, e lesão corporal seguida de morte, quando praticados contra agentes de segurança pública:

[...] este Projeto vem num momento muito importante da segurança pública do Brasil e da sociedade brasileira. Não seria razoável que esta Casa não se posicionasse no momento em que policiais das diversas forças estão sendo abatidos no Brasil, por enfrentarem o crime, especialmente o crime organizado. O Parlamento tem que reagir na defesa daqueles que defendem o povo, que defendem a sociedade. ${ }^{77}$

Os excertos transcritos mostram-se úteis no que diz respeito à tarefa de representação da função ontológica exercida pelas sinédoques engendradas pelos membros do Congresso Nacional com vistas à ampliação da normatividade da Lei dos Crimes Hediondos, a saber: a criação de identidades políticas coletivas que justificam, sob o pretexto de realização da ideia da representatividade democrática, a intensificação do "tratamento" jurídico-penal dispensado a certos crimes.

Neste sentido, é interessante observar que o todo, consubstanciado nas expressões "povo" e a "sociedade", representa, no limite, apenas uma parte da população brasileira:

76 BRASIL, 1998, p. 16883.

77 BRASIL, 2015, pp. 1-2. 
um "povo" cuja identidade se confunde, metaforicamente, com a figura da vítima (real ou potencial) da criminalidade violenta. Assim, a afirmação, via sinédoque, do caráter supostamente superlativo da identidade "povo-vítima" exsurge como precondição lógica para a afirmação do caráter hegemônico da reposta jurídico-penal.

Finalmente, a figura da catacrese denota um tipo de deslocamento retórico no qual "um termo figurativo não pode ser substituído por um termo literal" em função da existência de um "bloqueio constitutivo da/na linguagem", que não dispõe de palavras específicas para expressar, sem a necessidade de mediações, o significado da coisa ou fenômeno. ${ }^{78}$ Estamos diante de catacreses quando nos defrontamos com sentenças do tipo: veja a perna da cadeira, embarque no avião, o juiz é boca da lei. ${ }^{79}$ Sob o ponto de vista da sua operacionalização nos discursos políticos, a catacrese visa atribuir a um determinado signo linguístico a tarefa de representar outra ideia para além daquela que o seu uso pragmático costuma expressar.

Se as coisas são assim, julgamos que a vocação catacrética do significante "hediondo" pode ser vislumbrada a partir da constatação de que a preservação do seu caráter inominável exerce uma importante função estrutural no interior dos discursos analisados, qual seja: sobredeterminar o significado da expressão crime, propiciando, destarte, que o termo passe a expressar algo que o seu significado literal não consegue e nem poderia (no interior de um Estado Democrático de Direito fundado no ideal de promoção da dignidade da pessoa humana) comunicar: a ideia de que há, no espaço comunitário, certos sujeitos que, em virtude da excepcionalidade das suas ações, podem ser destituídos

78 LACLAU, 2013, p. 121.

79 A catacrese em questão foi problematizada por MACHADO (2013). 
da sua condição de cidadão e representados como inimigos internos ${ }^{80}$, que mereceriam ser submetidos a uma dinâmica normativa igualmente excepcional baseada, unicamente, no ideal da radicalização da intervenção jurídico-penal, na sua redução à condição de reação institucional incapacitante.

Essa função "estrutural", ou, melhor dizendo, "estruturante", desempenhada pela opção pela indeterminação jurídica do "hediondo" revela que o significante, interpretado à luz da figura da catacrese, parece servir como nome do locus discursivo onde as dimensões do direito e do seu contrário são sobrepostas, onde o inominável pode finalmente transparecer como jurídico:

Esse espaço vazio de direito parece ser, sob alguns aspectos, tão essencial à ordem jurídica que esta deve buscar, por todos os meios, assegurar uma relação com ele, como se, para se fundar, ela devesse manter-se necessariamente em relação com uma anomia. Por um lado, o vazio jurídico de que se trata no estado de exceção parece absolutamente impensável pelo direito; por outro lado, esse impensável se reveste, para a ordem jurídica, de uma relevância estratégica decisiva e que, de modo algum, se pode deixar escapar. ${ }^{81}$

À guisa de conclusão, quer-nos parecer que o inominável (ou o "impensável", como quer Agamben) que se expressa através do movimento catacrético resultante da sobredeterminação do termo crime pelo significante hedion-

80 Ao refletir acerca da permanência da noção de "inimigo" (hostis) nos discursos relacionados ao direito penal, Zaffaroni realiza uma leitura que, a nosso sentir, sintetiza, como nenhuma outra, o caráter oblíquo dos discursos que reivindicam, face à constatação da excepcionalidade de determinadas ações, a necessidade de um recrudescimento igualmente excepcional da reposta penal: "Em geral, a categoria do inimigo não é expressamente introduzida ou não são feitas referências claras a ela no direito ordinário, visto que ao menos intui-se sua incompatibilidade com o princípio do Estado de direito. Porém, com má consciência, legitima-se ou ignora-se o tratamento que, naquelas condições, é atribuído a um número enorme de pessoas". (ZAFFARONI, 2007, p. 190).

81 AGAMBEN, 2014, p. 79. 
do pode, afinal, ser nomeado caso estejamos prontos para romper com aquilo que se poderia denominar como razão cínica penal. ${ }^{82}$

É dizer, o inominável nominado pela significante "hediondo" é uma tendência político-criminal autorreferente que abandonou por completo a necessidade de se pensar a legislação penal como um lastro ético estruturante das ações do sistema de justiça criminal, vale dizer, como limite normativo para os excessos protagonizados pelo lupus artificialis e sua matilha. ${ }^{83}$ Com efeito, não há ética possível quando os destinatários das normas penais e processuais penais são representados como inimigos a serem eliminados ${ }^{84}$, senão pela morte, então pelo banimento viabilizado pela instituição de penas cada vez mais longas e pelo delineamento de procedimentos penais unicamente a partir do prisma da sua eficiência/responsividade punitiva. ${ }^{85}$

82 Autores como Slavoj Žižek ajudam a vislumbrar como esse tipo de comportamento, a inculcação da resposta jurídico-penal como um dogma, que se fundamenta por uma espécie de razão cínica que, subvertendo o sentido da clássica formulação marxista (ideologia como falsa consciência: "eles não sabem o que fazem, mas mesmo assim o fazem"), se apoia na crença, lampedusiana por excelência, segundo a qual: se algo deve mudar, mudese então de tal forma que tudo permaneça como está. A partir da leitura proposta por Žižek, essa razão cínica teria por escopo dissimular/ocultar o fundo (ou fundamento) obsceno da lei que se procura aplicar, da ordem que se intenta estruturar ou, ainda, das decisões políticas que se busca legitimar. Deste modo, no campo do debate ideológico contemporâneo, em vez de se cogitar que "eles não sabem, mas o fazem", ou mesmo de se argumentar que "eles sabem muito bem, mas fazem assim mesmo" (SLOTERDIJK, 1987, p. 218), dever-se-ia ter em mente que o fato de que os ideólogos atuais "sabem muito bem que, em sua atividade real, pautam-se por uma ilusão, mas, mesmo assim, continuam a fazê-lo". (ŽIŽEK, 1992, p. 63).

83 FERRAJOLI, 2010, p. 861.

84 É interessante observar como em nenhum dos discursos parlamentares analisados os autores das infrações penais (re)significadas como "hediondas" foram representados como cidadãos dotados de direitos e garantias constitucionais.

85 GLOECKNER, 2009, pp. 419-420. 
O desvelamento da vocação catacrética do hediondo denota, demais disso, o fato de que a expressão representa também um dispositivo ${ }^{86}$ a serviço do estado de exceção ${ }^{87}$, sobretudo na medida em que representa, na esteira da compreensão assentada por Carl Schmitt: "a forma legal daquilo que não pode ter forma legal".$^{88}$

Resta ainda explicitar uma última implicação decorrente dessa leitura que considera o hediondo uma catacrese: a vontade política inominável que se estampa no apelo catacrético ao significante hediondo parecer designar, ademais do que se disse até então, a existência de uma confusão fundamental que, no entendimento de Zaffaroni, é própria de Estados Democráticos de Direito cujos fundamentos se encontram em franco processo de degradação: “o direito penal permitiu a introdução do inimigo - seja com o nome que for - e, com isso, confundiu, ao longo de quase toda a sua história, o momento da guerra com o da política" ${ }^{89}$.

86 Importante esclarecer que quando cogitamos do hediondo como um dispositivo, partimos do sentido atribuído ao termo por Giorgio Agamben: “[...] generalizando a já amplíssima classe dos dispositivos foucaultianos, chamarei literalmente de dispositivo qualquer coisa que tenha de algum modo a capacidade de capturar, orientar, determinar, interceptar, modelar, controlar e assegurar os gestos, as condutas, as opiniões e os discursos dos seres viventes". (AGAMBEN, 2009, p. 40).

87 Em uma das mais bem acabadas reflexões sobre tema, Agamben argumentará que a noção de estado de exceção ilustra a dinâmica decisória do totalitarismo moderno que opera a partir da criação de uma "guerra civil legal que permite a eliminação física não só dos adversários políticos, mas também de categorias interias de cidadãos que, por qualquer razão, pareçam não integráveis ao sistema político". (AGAMBEN, 2014, p. 13).

88 AGAMBEN, 2009, p. 12.

89 ZAFFARONI, 2007, p. 191. 


\section{Considerações finais}

Ao longo deste trabalho, tivemos a oportunidade de testar essa hipótese que sugere que a Retórica e as suas figuras de linguagem possuem valor heurístico para a realização de análises discursivas, de corte político-criminal, fundadas em termos filosófico-linguísticos.

No intuito de realizar o objetivo delineado logo no início deste artigo, desenvolvemos quatro linhas argumentativas. Cada uma dessas delas foi trabalhada à luz de uma determinada figura da Retórica. Num primeiro momento, debatemos a centralidade da metáfora para a compreensão do processo de significação da realidade que serve de fundamento para a afirmação do caráter hegemônico da intervenção jurídico-penal; por conseguinte, identificamos a natureza metonímica dos significantes atualmente mobilizados para a construção da identidade da magistratura criminal; em seguida, ressaltamos a importância da sinédoque para a compreensão da dinâmica do processo discursivo de construção das identidades políticas coletivas invocadas pela discursividade parlamentar relacionada ao universo normativo da Lei dos Crimes Hediondos; por fim, discorremos brevemente acerca da vocação catacrética do hediondo, um significante que, pelas razões já expostas, não apenas opera no interior da discursividade parlamentar como o nome do impensável, como também representa um verdadeiro dispositivo de exceção no âmbito do ordenamento jurídico brasileiro.

O desenvolvimento dessas quatro linhas argumentativas pressupôs, no entanto, a explicitação do significado atribuído a duas noções fundamentais e interdependentes extraídas da teoria do discurso de Ernesto Laclau: Discurso e Retórica. A primeira noção, lembremos, coloca em evidência o estatuto ontológico da noção de discurso, que é 
representada, pelo autor, como locus que abriga o processo de construção da objetividade dos signos que compõem a realidade social. Segue-se daí que a própria noção de objetividade é produto de um processo de significação que não pode prescindir da observância de certas condições discursivas de emergência.

Se a noção de discurso denota, como crê Laclau, o território primário da formação da objetividade dos fenômenos e das relações sociais, que papel cabe à Retórica? Assumir a concepção de discurso preconizada pelo autor significa, dentre outras questões, repudiar a dicotomia estampada na oposição: literalidade versus figuração. É no intuito de demonstrar que literalidade e figuração não são essencialmente níveis distintos de um processo de representação da realidade, mas sim momentos que pertencem a um mesmo continuum, que a retórica e suas figuras de linguagem passam a adquirir importância. Invertendo a ordem "natural" pressuposta pela crítica ao caráter manipulatório da retórica, essa teoria do discurso abdicará de interpretar os deslocamentos tropológicos como tentativas malfadadas de falsificação ou adorno do "verdadeiro" significado dos significantes mobilizados no interior de um discurso. No lugar deste entendimento adotar-se-á outro, a saber, de que a "retoricidade é inerente à significação" 90 , quer dizer, que os deslocamentos semânticos ilustrados pela Retórica e suas figuras são, a rigor, elementos indispensáveis para a construção (hegemônica) do caráter literal/objetivo da realidade social.

Feitos esses esclarecimentos, podemos agora tentar responder ao questionamento que, ainda que de forma indireta, foi suscitado logo nas primeiras linhas deste artigo: goza a Retórica de algum valor heurístico para a análise dos discursos político-criminais? Acreditamos que sim, sobretudo na

90 LACLAU, 2011, p. 195. 
medida em que identificamos que a "realidade", que serve de justificativa para a ampliação da normatividade penal, tem o seu sentido estabilizado, em larga escala, por metáforas, sinédoques e, em alguns casos particulares, por catacreses.

Antes de encerramos as nossas reflexões, caberia indagar: para além do seu valor descritivo, poderia a Retórica embasar a realização de uma leitura crítica acerca da discursividade político-criminal contemporânea? A reposta, intuímos, também é positiva.

A fim de melhor embasarmos a nossa resposta, finalizaremos este artigo destacando como a compreensão da relação que se estabelece entre as figuras da metáfora e da metonímia poderia contribuir para formulação de uma crítica radical às associações simbólicas encerradas nos deslocamentos retóricos que se colocam a serviço do poder punitivo. A opção pelo escrutínio analítico dessa relação tropológica em particular se justifica na medida em que ela representa, como observa Laclau, a mais antiga relação de oposição estudada pela Retórica: contingência versus necessidade. ${ }^{91}$

Propomos iniciar a nossa derradeira reflexão pela explicitação de uma proposição nada estranha aos estudos criminológicos de orientação crítica: tanto a opção pela criminalização de uma determinada conduta humana como a opção pela sua qualificação como "hedionda" são decisões políticas tomadas a partir de um terreno indecidível ${ }^{92}$, que

91 LACLAU, 2015, p. 87.

92 A noção de indecidibilidade deriva das considerações realizadas por Jacques Derrida acerca dos conceitos de decisão e indeterminação. Indagado acerca do sentido que atribui à noção, Derrida esclarece: “[...] indecidibilidade não é indeterminação. Indecidibilidade é a competição entre duas oportunidades ou opções determinadas [...]. Agora porque há contextos e singularidades, há movimentos, processos e transformações, e para que uma transformação ocorra algo tem de estar determinado, algo é determinável". (CAPUTO, 2002, p. 45). 
se caracteriza enquanto tal pelo simples fato de que, ao tempo da tomada da decisão, outras opções eram igualmente possíveis.

Caso estejamos de acordo com tal proposição, seremos levados a refletir sobre uma segunda, essa sim mais diretamente relacionada ao tipo de análise que propusemos realizar neste artigo: considerando que o processo primário de criminalização não obedece a nenhuma necessidade lógica ou lei imanente a exigir, a priori, a tomada de uma decisão político-criminal em detrimento de outras igualmente possíveis, inevitável é concluir que a relação estabelecida entre os significantes: "pena" e "conflitividade social" é essencialmente metonímica.

Vimos, no entanto, que o caráter contingente dessa relação (metonímica) costuma ser obnubilado pela discursividade parlamentar que, lançando mão de totalizações metafóricas ${ }^{93}$, defende, sobretudo nos debates que gravitam em torno da Lei dos Crimes Hediondos, a necessidade de se reagir a um determinado conflito social mediante a intensificação do tratamento jurídico-penal.

Se as coisas são assim, se o recrudescimento da política criminal contemporânea inevitavelmente depende da realização de totalizações metafóricas cuja implicação mais imediata é a ocultação da contiguidade contingente inerente às relações metonímicas, é porque o fenômeno de expansão do direito penal, a despeito do que se costuma afirmar, não é o destino manifesto dos sistemas jurídico-penais contem-

93 O caráter totalizante, e, logo, estruturante, da metáfora pode ser claramente observado nas constantes referências realizadas pelos discursos que discutem a questão criminal às figuras do "contrato social", do "estado de natureza" e do "corpo social". Como observa Zaffaroni, essas imagens são invenções que, mesmo carecendo de uma realidade antropologicamente fundada, servem de fundamento para os argumentos (sistêmico-funcionalistas) de legitimação do sistema de justiça criminal. (ZAFFARONI, 2010, p. 49). 
porâneos; dita tendência representa o produto final, embora não definitivo, de uma opção política pautada pela tomada de decisões indecidíveis, que podem (em virtude da sua própria natureza) ser revertidas a partir: (i) da desconstrução da necessidade que lhes dá amparo; (ii) da reativação do caráter contingente da associação metonímica entre os significantes pena e conflitividade social, algo que poderia ser feito a partir do desenvolvimento de soluções alternativas relativamente ao enfrentamento daquilo que Louk Hulsman chamou de "situações-problema". ${ }^{4}$

Por óbvio é possível pensar, a médio e longo prazo, alternativas ao atual e desalentador cenário da política criminal brasileira. Ainda assim, é fundamental ter em mente que a não denúncia da contiguidade metonímica que se estabelece entre os significantes: "pena" e "conflitividade social" contribui para a consolidação da ideia de que o primeiro significante representa metaforicamente o segundo, vale dizer, que a tutela jurídico-penal consubstancia, a despeito de todos os postulados preconizados pela tradição penal liberal, prima ou sola ratio frente a toda sorte de conflitividade social. Esse tipo de cristalização metafórica do sentido atribuído à pena permite chegar ao extremo de se cogitar um cenário no qual todos os conflitos sociais serão, direta ou indiretamente,

94 No entendimento de Hulsman, a quebra da hegemonia do poder punitivo não passa apenas pela recusa da solução-prisão em um nível institucional. A dissolução da vontade de punir pressupõe, igualmente, a realização daquilo que o autor chamou de um "abolicionismo acadêmico", uma revolução a ser protagonizada no campo da linguagem teórica utilizada para descrever/ criticar o funcionamento do poder punitivo: "[...] chamar um fato de 'crime' significa excluir de antemão todas essas outras linhas; significa se limitar ao estilo punitivo - o estilo punitivo da linha sócio-estatal, ou seja, um estilo punitivo dominado pelo pensamento jurídico, exercido com uma distância enorme da realidade por uma rígida estrutura burocrática. Chamar um fato de 'crime' significa se fechar de antemão nesta opção infecunda". (HULSMAN, 1993, p. 100-101). 
administrados pela tutela jurídico-penal, de forma direta ou indireta, mediata ou imediata.

Se chegarmos a vivenciar tal realidade - a despeito das muitas possibilidades de resistência concebidas pela ordem democrática - estaremos, muito possivelmente, às voltas com o momento da abolição do Estado de Direito e da consequente instituição de um Estado Policial de Exceção ${ }^{95}$, onde o gozo das liberdades civis e dos direitos políticos encontrar-se-á, uma vez mais, subordinado à vontade de um ente soberano que, por definição, dispõe da capacidade de suspender a ordem jurídica através de decisões que exaltam necessidades ${ }^{96}$ que não conhecem limites. ${ }^{97}$

Malgrado o diagnóstico, é necessário reconhecer: ao perscrutarmos os deslocamentos retóricos operados no interior dos discursos selecionados, vislumbramos a possibilidade de esboçarmos algo que, na falta de uma melhor expressão, poderíamos chamar de "resistência metonímica", uma espécie de contramovimento de significação cujo plano

95 Agamben ilustra, com precisão, no que consiste, contemporaneamente, a violência despótica manejada por aquilo que - partindo de Zaffaroni - chamamos anteriormente de Estado Policial de Exceção: “O estado de exceção, hoje, atingiu seu máximo desdobramento planetário. $\mathrm{O}$ aspecto normativo do direito pode ser assim impunemente eliminado e contestado por uma violência governamental, que [...] ao produzir no âmbito interno um estado de exceção permanente, pretende, no entanto, ainda aplicar o direito". (AGAMBEN, 2004, p. 131).

96 É curioso perceber que os discursos parlamentares analisados atribuem às ideias de "necessidade", "exceção" e "decisão", um tratamento muito próximo daquela dispensado por Schmitt, para quem: “O soberano não só decide sobre a existência de um perigo emergencial extremo, mas também o que deve ser feito para eliminá-lo [...]. Ele se situa externamente à ordem legal vigente, mas mesmo assim pertence a ela, pois é competente para decidir sobre a sua suspensão total”; “[...] cada ordem baseia-se numa decisão, e também o conceito de ordem jurídica, aplicado como algo natural, baseia-se, ele próprio, numa decisão e não numa norma". (SCHMITT, 1996, p. 88 e 90).

97 ZAFFARONI, 2007, p. 192; SCHMITT, 1996, p. 87. 
de ação pode ser encontrado na alternativa proposta por Giorgio Agamben ao Estado de Exceção:

Se é possível deter a máquina [o estado de exceção], mostrar a sua ficção central, é porque, entre violência e direito, entre a vida e a norma, não existe nenhuma articulação substancial. Ao lado de um movimento que busca, a todo custo, mantê-los em relação, há um contramovimento que, operando em sentido inverso no direito e na vida, tenta, a cada vez, separar o que foi artificial e violentamente ligado. ${ }^{98}$

Acreditamos que a principal lição a ser inferida da conclusão referendada pelo filósofo italiano é a seguinte: uma das funções primordiais de uma crítica linguisticamente fundada, sensível aos deslocamentos retóricos que operam no âmbito dos processos de significação engendrados pela discursividade parlamentar de corte punitivista, consiste no empreendimento de esforços para expor: (i) o caráter "impuro" da sinédoque que eleva o "povo", e seus sinônimos, à condição de um referente "empírico" de legitimação de processos legislativos de criminalização; (ii) a natureza essencialmente metonímica, é dizer, precária e contingente, dessa relação de referência - que atualmente beira à alusão metafórica - que se estabelece, sobretudo nos discursos sobre o hediondo, entre os significantes "pena" e "conflitividade social". Destarte, se é verdade que, como quer fazer crer Correa, "[e]l discurso del poder camina por el carril de la Retórica" ${ }^{\prime 99}$, cumpre conhecer as lógicas que determinam o traçado da pista por onde a razão (punitiva) trafega.

98 AGAMBEN, 2004, p. 132.

99 CORREA, 2013, p. 90. 


\section{Referências bibliográficas}

AGAMBEN, Giorgio. Estado de exceção (Col. Estado de Sítio). $2^{a}$ ed. rev.. São Paulo: Boitempo, 2014.

. O que é dispositivo? In: O que é o contemporâneo e outros ensaios. Chapecó, SC: Argos, pp. 25-54, 2009.

ARISTÓTELES. Retórica (Trad. Manuel Alexandre Júnior; Paulo Farmhouse Alberto; Abel do Nascimento Pena). Lisboa: Imprensa Nacional, 2005.

BATISTA, Nilo; ZAFFARONI, Eugenio Raúl; ALAGIA, Alejandro; SLOKAR, Alejandro. Direito Penal Brasileiro, Vol. I. Rio de Janeiro: Revan, 2011.

BURITY, Joanildo Albuquerque. Discurso, política e sujeito na teoria da hegemonia de Ernesto Laclau. In: Pós-estruturalismo e teoria do discurso: em torno de Ernesto Laclau. $2^{\text {a }}$ Ed. Porto Alegre: EDIPUCRS, pp. 59-74, 2014.

BUTLER, Judith. Fundamentos contingentes: o feminismo e a questão do pós-modernismo. In: Cadernos Pagu, n. 11, pp. 11-42, 1998.

CAPUTO, John. Por amor às coisas mesmas: o hiper-realismo de Derrida. In: Às margens: a propósito de Derrida. DUQUE-ESTRADA, Paulo Cesar (Org.). Rio de Janeiro: Ed. PUC-Rio; São Paulo: Loyola, 2002.

CARVALHO, Salo de. O encarceramento seletivo da juventude negra brasileira: a decisiva contribuição do poder judiciário. In: Rev. Fac. Direito UFMG, Belo Horizonte, n. 67, jul/dez, pp. 623-652, 2015.

CORREAS, Óscar. Razón, retórica y derecho: la racionalización de la retórica. In: Revista Brasileira de Estudos Políticos, v. 106, pp. 69-94, 2013. 
DAMASCENO, Maria Helena; MEGALE, Silva. Uma recordação da Retórica no Fedro de Platão ou a Força de Resposta do Discurso Juspolítico Inspirado na Idéia de Justiça. In: Revista Brasileira de Estudos Políticos, v. 98, pp. 337-360, 2008.

DERRIDA, Jacques. A escritura e a diferença. São Paulo: Perspectiva, 2014.

. ROUDINESCO, Elizabeth. De que amanhã... Diálogos. Tradução por André Telles. Rio de Janeiro: Jorge Zahar Editor, 2004.

DUNKER, Christian Ingo Lenz; ASSADI, Tatiana Carvalho. Alienação e separação nos processos interpretativos em psicanálise. In: Psyche, São Paulo, v. 8, n. 13, junho, pp. 85-100, 2004.

FRADE, Laura. Quem mandamos para a prisão? Visões do parlamento sobre a criminalidade. Brasília: Líber Livro Editora, 2008.

FERRAJOLI, Luigi. Direito e razão: teoria do garantismo penal. $3^{\text {a }}$ ed. rev. São Paulo: Editora Revista dos Tribunais, 2010.

FEYERABEND, Paul Karl. Contra o método. $2^{\mathrm{a}}$ ed. São Paulo: Editora Unesp, 2011.

FRANCO, Alberto Silva. Crimes Hediondos: anotações sistemáticas à Lei 8.072/90. $4^{\text {a }}$ Ed. São Paulo: RT, 2000.

GAZOTO, Luís Wanderley. Justificativas do Congresso Nacional Brasileiro ao rigor penal legislativo. Diss. Universidade de Brasília, Brasília, 2010.

GLOECKNER, Ricardo Jacobsen. Risco e processo penal: uma análise a partir dos direitos fundamentais do acusado. Bahia: JusPodivm, 2009.

GLYNOS, Jason; HOWARTH, David. Logics of Critical Ex- 
planation in Social and Political Theory. New York: Routledge, 2007.

GOMES, Luiz Flávio; ALMEIDA, Débora de Souza de. Populismo penal midiático: caso mensalão, mídia disruptiva e direito penal crítico. São Paulo: Saraiva, 2013.

HULSMAN, Louk; CELIS, Jacqueline Bernat de. Penas Perdidas. Niterói: Luam, 1993.

KANT, Immanuel. Crítica da Faculdade do Juízo. Tradução de Valério Rohden e Antônio Marques. 2a edição. Rio de Janeiro: Forense Universitária, 2002.

LACLAU, Ernesto. A Razão Populista. São Paulo: Três Estrelas, 2013.

. The Rhetorical Foundations of Society. London: Verso, 2014.

. New refletions on the revolution of our time. London: Verso, 1990.

. Posfácio. In: MENDONÇA, Daniel de; RODRIGUES, Léo Peixoto (orgs.). Pós-estruturalismo e teoria do discurso: em torno de Ernesto Laclau. Porto Alegre: EDIPUCRS, pp. 207-209, 2014.

. MOUFFE, Chantal. Hegemonia e estratégia socialista. São Paulo: Intermeios, 2015.

. MOUFFE, Chantal. Pós-marxismo sem pedido de desculpas. In: LOPES, Alice Casimiro; MENDONÇA, Daniel de (orgs.). A teoria do discurso de Ernesto Laclau: ensaios críticos e entrevistas. São Paulo: Annablume, pp. 35-72, 2015b.

Articulação e os limites da metáfora. In: LOPES, Alice Casimiro; MACEDO, Elisabeth. Emancipação e Diferença. Rio de Janeiro: EduUERJ, pp. 183-216, 2011. 
MACHADO, Igor Suzano. Jurisdição, hegemonia e integridade: uma visão pós-estruturalista sobre o direito e sua relação com a sociedade e a política no Brasil. In: Dados, Rio de Janeiro, v. 56, n. 4, dezembro, pp. 943-974, 2013.

LÉVI-STRAUSS, Claude. Mito e significado. Portugal: Edições 70, 1987.

MARCHART, Oliver. Post-foundational political thought: political difference in Nancy, Badiou and Laclau. Edinburgh: Edinburgh University Press, 2007.

MENDONÇA, Daniel de. O limite da normatividade na teoria política de Ernesto Laclau. In: Lua Nova: Revista de Cultura e Política, n. 91, São Paulo, pp. 135-169, 2014.

. O Momento do Político: Evento, Indecidibilidade e Decisão. In: Dados, Rio de Janeiro, v. 57, n. 3, set., pp. 745771, 2014.

RODRIGUES, Léo Peixoto. Do estruturalismo ao pós-estruturalismo: entre fundamentar e desfundamentar. In: MENDONÇA, Daniel de; RODRIGUES, Léo Peixoto (orgs.). Pós-estruturalismo e teoria do discurso: em torno de Ernesto Laclau. $2^{a}$ Ed. Porto Alegre: EDIPUCRS, pp. 27-57, 2014.

MOUFFE, Chantal. O regresso do político. Traduzido por Ana Cecília Simões. Portugal: Gradiva, 1996.

ledge, 2005.

On the political: thinking in action. London: Rout-

PAIVA, Luiz Guilherme Mendes de. A fábrica de penas: racionalidade legislativa e a lei dos crimes hediondos. Rio de Janeiro: Revan, 2009.

PLATÃO. Górgias. In: PLATÃO. Protágoras, Górgias, Fedão. Traduzido por Carlos Alberto Nunes. Belém: EDUFPA, 2002. 
PRATT, John. Penal Populism. New York: Routledge, 2007.

REIS, Issac. Análise empírico-retórica do Discurso Constitucional: uma contribuição metodológica à pesquisa de base em direito. In: RODRIGUES, Horário Wanderlei (coord.) et al. Direito, Educação, Ensino e Metodologia Jurídicas. Florianópolis: CONPEDI, pp. 73-93, 2014.

RICOEUR, Paul. The Political Paradox. In: History and Truth. Evanston: Northwestern University Press, pp. 247270, 1957.

SAUSSURE, Ferdinand de. Curso de linguística geral. $28^{\circ}$ ed. São Paulo: Cultrix, 2014.

SCHMITT, Carl. A crise da democracia parlamentar. São Paulo: Scritta, 1996.

. The Concept of Political. Traduzido por George Schwab. Chicago: Chicago University Press, 2007.

SLOTERDIJK, Peter. Critique of Cynical Reason. Minneapolis: University of Minnesota Press, 1987.

ZAFFARONI, Eugenio Raul. O inimigo no direito penal. $2^{\mathrm{a}}$ Ed. Rio de Janeiro: Revan, 2007.

Em busca das penas perdidas, $1^{a}$ reimpressão, Rio de Janeiro: Revan, 2010.

ŽIŽEK, Slavoj. Eles não sabem o que fazem: o sublime objeto da ideologia. Rio de Janeiro: Jorge Zahar Editor, 1992.

. Como Marx inventou o sintoma? In: ZIZEK, Slavoj (org). Um mapa da ideologia. Rio de Janeiro: Contraponto, 1996. 


\section{Fontes consultadas}

ANISTIA INTERNACIONAL. Informe sobre a situação prisional - Relatório 2014-2015. Disponível em: www.anistia. org.br. Acesso em 15 de Outubro de 2015

BRASIL. Senado Federal. Projeto de Lei no 50/1990. Dispõe sobre os crimes hediondos, nos termos do art. $5^{\circ}$, inciso XLIII, da Constituição Federal, e determina outras providências. 1990. Disponível em: www.senado.leg.br. Acesso em: 13 mar. 2017.

. Câmara dos Deputados. Projeto de Lei $n^{\circ}$ 4.146/1993. Dá nova redação ao artigo primeiro da lei $n^{\circ}$ 8.072, de 25 de julho de 1990, que dispõe sobre os crimes hediondos, nos termos do artigo $5^{\circ}$, inciso XLIII, da constituição federal, e determina outras providências. 1994. Disponível em: www.camara.leg.br. Acesso em: 13 mar. 2017.

. Câmara dos Deputados. Projeto de Lei $n^{\circ}$ 4.628/1998. Acrescenta o inciso VIII ao art. $1^{\circ}$ da Lei $n^{\circ} 8.072$, de 1990, que dispõe sobre os crimes hediondos. 1998. Disponível em: www.camara.leg.br. Acesso em: 13 mar. 2017.

. Câmara dos Deputados. Projeto de Lei $\mathrm{n}^{\mathrm{o}}$ 846/2015. Altera os arts. 121 e 129 do Decreto-Lei no 2.848, de 7 de dezembro de 1940 - Código Penal, e o art. $1^{\circ}$ da Lei no 8.072, de 25 de julho de 1990 - Lei dos Crimes Hediondos. 2015. Disponível em: www.camara.leg.br. Acesso em: 13 mar. 2017. 
Recebido em 23/03/2018.

Aprovado em 23/04/2018.

\section{Ricardo Jacobsen Gloeckner \\ E-mail: ricardogloeckner@hotmail.com}

Marcelo Buttelli Ramos

E-mail: buttelliadv@gmail.com 